\title{
The Potencial of Campomanesia phaea O. Berg Landrum (Cambuci) as Natural Source of Vitamin C
}

\author{
By Marcelo Machado Leao* \\ Giovanna Fachini Dellaqua ${ }^{\dagger}$ \\ Marcos David Ferreira \\ Silviane Zanni Hubinger ${ }^{+}$ \\ Marcia Ortiz Mayo Marques \\ Marta Helena Filet Spoto
}

Fruit is an essential part of a healthy diet preventing risks. This protective action has been attributed mainly to its bioactive compounds, which have antioxidant properties. Ascorbic acid, also named vitamin $C$, is the most important water-soluble reducing compound naturally present in fruit and vegetables that contributes to antioxidant defense against oxidative stress. Vitamin $C$ is often used as a nutritional quality indicator of fruit and vegetables. Still little is known scientifically for the endemic species in Brazil's São Paulo State located in the Atlantic Forest biome, the Campomanesia phaea (O.Berg) Landrum (cambuci) from the family of Myrtaceae, traditionally used by communities in this region. This study evaluated the cambuci fruit in nature and the fruit pulp when submitted to different conservation treatments for the evaluation of levels of vitamin C (L-ascorbic acid), an important indicator of the quality of fruits and foods during processing and storage. The evaluation of the vitamin C content was performed by High-Performance Liquid Chromatography (HPLC), when subjected to pasteurization and freezing during different periods of conservation. The results showed that the cambuci have average significant levels of L-ascorbic acid (66.94mg / $100 \mathrm{~g}$ of cambuci). After the agro-industrial treatments, the pulp showed significant decreases $(p \leq 0.05)$ of L-ascorbic; however, it still exhibited significant mean levels, the initial content being $51.04 \mathrm{mg} / 100 \mathrm{~g}$ cambuci, for frozen pasteurized pulp and $62.15 \mathrm{mg} / 100 \mathrm{~g}$ cambuci to frozen pulp. Thus, the study showed that the inclusion of Campomanesia phaea (cambuci) in the human diet could be an alternative source to provide vitamin $C$, and could provide opportunities, employment and income increase for traditional communities, stimulating the growth for an important local business chain, taking advantage of the Brazilian biodiversity.

Keywords: Atlantic Forest biome, Cambuci, Campomanesia phaea, Fruit pulp, Lascorbic acid, Vitamin $C$.

\footnotetext{
${ }^{*}$ Scientific Researcher, University of Sao Paulo (ESALQ/USP), Brazil.

${ }^{\dagger}$ Master Student, University of Sao Paulo (ESALQ/USP), Brazil.

* Scientific Researcher, Brazilian Agricultural Research Corporation, Brazil.

${ }^{+}$Analyst A, Brazilian Agricultural Research Corporation, Brazil.

- Scientific Researcher, Agronomical Institute of Campinas, Brazil.

- Professor, University of Sao Paulo (ESALQ/USP), Brazil
} 


\section{Introduction}

The agribusiness of citrus's pulps, juices and tropical fruit is very relevant nowadays, mainly due to the association of consumption with health benefits. The species Campomanesia phaea (O. Berg.) Landrum popularly known in Brazil as "cambuci" or "cambucizeiro" (Myrtaceae) is included in the subfamily Myrtoideae. In Brazil, it naturally occurs in the states of São Paulo, mainly in the Serra do Mar (Lorenzi, 2014).

The fruit of Campomanesia phaea is exotic, with interesting aromatic properties as flavouring agents. They are used by the local population in foods and beverages as juice, ice cream, jellies and sweets to stress the flavour (Adati and de Oliveira Ferro, 2006; Adati, 2001; Leão, 2012; Lorenzi, 2014; Mathias and Andrade, 2011). They are astringent and have antioxidant properties, so when included in products they may help in healthy diets (De Souza Schmidt Gonçalves et al., 2010; Donado-Pestana et al., 2015; Haminiuk et al., 2011).

The cambuci plant could be considered a rare fruit with high economic value and environmental impacts, which influences the local business chain and contributes to the sustainable development of local society (Adati, 2001; Adati and de Oliveira Ferro, 2006; Kawasaki and Landrum, 1997; Leão, 2012).

Fruit is an essential part of a healthy diet in order to prevent health risks. These include aging -induced oxidative stress, cardiovascular disorders, diverse degenerative diseases and inflammatory responses (Block et al., 1992; Kalt et al., 1999; Nicoli et al., 1999; Zafra-Stone et al., 2007). This protective action has been attributed mainly to cambuci fruit bioactive compounds, which have antioxidant properties as L-ascorbic and compound phenolic.

L-Ascorbic acid, also named vitamin $\mathrm{C}$, is the most important watersoluble reducing compound naturally present in fruit and vegetables that contribute to antioxidant defense against oxidative stress (Jayaprakasha and Patil, 2007; Plaza et al., 2006). However, ascorbic acid is readily oxidized and lost in pulp and juices, so the rates depend on the time of processing and/or conditions of storage. Because of its heat-labile properties and instability, it is often used as an indicator of the nutritional quality of foods (Cortes et al., 2008; Polydera et al., 2003; Zulueta et al., 2010). Because of its heat-labile properties and instability during storage, ascorbic acid is often used as an indicator for the overall quality of fruit and vegetables, providing information about loss of other vitamins as well as organoleptic and/or nutritional components (Cortes et al., 2008; Polydera et al., 2003; Zulueta et al., 2010).

The fruit pulp technology process is a conservation method that extends self-life allowing its commercialization in different periods of the year and in different forms. Thus, the processing of vegetables generally shows an interesting possibility for their commercial use. Thermal pasteurization is one of the most widely applied techniques to ensure the conservation of pulp, successful in preventing enzymatic changes and microbial spoilage ensuring food safety and improving the shelf life of the product (Abid et al., 2014; Asami et al., 2003). However, thermal decomposition is the most common 
cause of undesirable biochemical changes, especially antioxidants that affect the sensory and nutritional quality of the final product (Abid et al., 2014; Aguilar-Rosas et al., 2007; Rawson et al., 2011).

This study evaluated the vitamin C levels in the pulp of cambuci fruit in its natural state and when submitted to different conservation treatments, as Lascorbic acid is an important indicator of the quality of fruit and foods during processing and storage.

\section{Materials and Methods}

\section{Fruit Pulps}

Plant materials: Composite samples from the fruit of Campomanesia phaea (O. Berg.) Landrum (cambuci) were collected in the natural zone area of the species: the cities of Paraibuna and Natividade da Serra, both in the state of São Paulo/Brazil. Those locations are classified as Tropical Rain Forests (TRF).

Pulps: The analyzed pulps were obtained after processing the plant materials at the Department of Agroindustry, Food and Nutrition (LAN) at the College of Agriculture "Luiz de Queiroz" (ESALQ/USP) (Departamento de Agroindústria, Alimentos e Nutrição - LAN - da Escola de Agronomia "Luiz de Queiroz" - ESALQ/USP) in Piracicaba, State of São Paulo.

\section{Ascorbic Acid Determination}

The analysis was carried out at the Empresa Brasileira de Pesquisa Agropecuária - Embrapa (EMBRAPA Instrumentation) in São Carlos, State of São Paulo.

The method applied was described by Bresolin \& Hubinger (Bresolin and Hubinger, 2014). The samples were processed to a known volume with metaphosphoric acid $3 \%(\mathrm{w} / \mathrm{v})$, filtered through a disposable filter of hydrophilic Teflon $(0,45 \mu \mathrm{m}$ porosity) and placed in a vial. The L-ascorbic acid was defined using an Agilent C18 column $(2.5 \times 25 \mathrm{~mm}, 5 \mu \mathrm{m})$, and phosphate buffer at $\mathrm{pH} 2.5$ as a mobile phase. The liquid chromatographer used as a pattern varied with UV-Visible detector set to $254 \mathrm{~nm}$ reading. The mobile phase flow rate was $1.0 \mathrm{ml} / \mathrm{min}$ and the injection volume was $20 \mu \mathrm{L}$. The Lascorbic acid (purity $\geq 99.0 \%$ ) used as a standard was obtained from Sigma Life Science. The entire experiment was performed in triplicate.

\section{Statistical Analysis}

This study adopted the range of a 5\% level. All inference procedures were preceded by average tests of Tukey. 


\section{Results and Discussion}

\section{Standard Ascorbic Acid Solution}

The correlation of standard ascorbic acid concentrations (x) vs measured (y) concentrations of ascorbic acid in the pulp of the cambuci fruit was determined by the analysis of standard solutions prepared from ascorbic acid. A correlation was calculated for each period (Table 1).

Table 1. Standard Solutions Equations for Each Period

\begin{tabular}{|c|c|}
\hline Day & Correlation of ascorbic acid $(\mathbf{x})$ vs concentrations $(\mathbf{y})$ \\
\hline 01 & $\mathrm{C}=(\mathrm{A}+3.5933) / 0.4923$ \\
\hline 15 & $\mathrm{C}=(\mathrm{A}+3.5933) / 0.4923$ \\
\hline 30 & $\mathrm{C}=(\mathrm{A}+0.4179) / 0.7417$ \\
\hline 45 & $\mathrm{C}=(\mathrm{A}+0.0624) / 0.7566$ \\
\hline 60 & $\mathrm{C}=(\mathrm{A}+0.7750) / 0.8042$ \\
\hline 75 & $\mathrm{C}=(\mathrm{A}-1.5329) / 0.7487$ \\
\hline 90 & $\mathrm{C}=(\mathrm{A}-1.5329) / 0.9970$ \\
\hline
\end{tabular}

C: Concentrations of ascorbic acid, A: Area of peak

\section{Fruit and Fruit's Pulp}

According to Table 2 and Graph 1, the initial vitamin $\mathrm{C}$ average in cambuci fruit presented $141.46 \%(66.94 \mathrm{mg} / 100 \mathrm{~g}$ pulp) more than in orange fruit $(47.32 \mathrm{mg} / 100 \mathrm{~g})$ and $179.04 \%$ more than in lemon fruit $(37.39 \mathrm{mg} /$ $100 \mathrm{~g}$ ). The orange juice is a highly valued product representing a significant source of vitamin C (Majo et al., 2005; Rapisarda et al., 2008; Ayhan et al., 2001; Bezman et al., 2001), thus the cambuci fruit can be an alternative source of vitamin $\mathrm{C}$.

Table 2. Average Levels of Vitamin C in Fruit

\begin{tabular}{|c|c|c|}
\hline Fruit & $\begin{array}{c}\text { Vitamin C mg/100 g of } \\
\text { pulp }\end{array}$ & $\begin{array}{c}\text { Average } \\
\mathrm{mg} / 100 \mathrm{~g} \text { of pulp }\end{array}$ \\
\hline Cambuci sample 1 & 45.074 & \multirow{3}{*}{66.94} \\
\hline Cambuci sample 2 & 74.847 & \\
\hline Cambuci sample 3 & 80.904 & \\
\hline Fresh Lime * & 37.39 & 37.39 \\
\hline Fresh navel orange* & 56.90 & \multirow{5}{*}{47.32} \\
\hline Citrus aurantium L.* & 34.70 & \\
\hline Fresh lime orange $*$ & 43.50 & \\
\hline Fresh flash orange $*$ & 53.70 & \\
\hline Fresh valencia orange $*$ & 47.80 & \\
\hline
\end{tabular}

*Tabela brasileira de composição de alimentos Campinas (NEPA-UNICAMP) 
Graphic 1. Average Levels of Vitamin C Content in Fruit

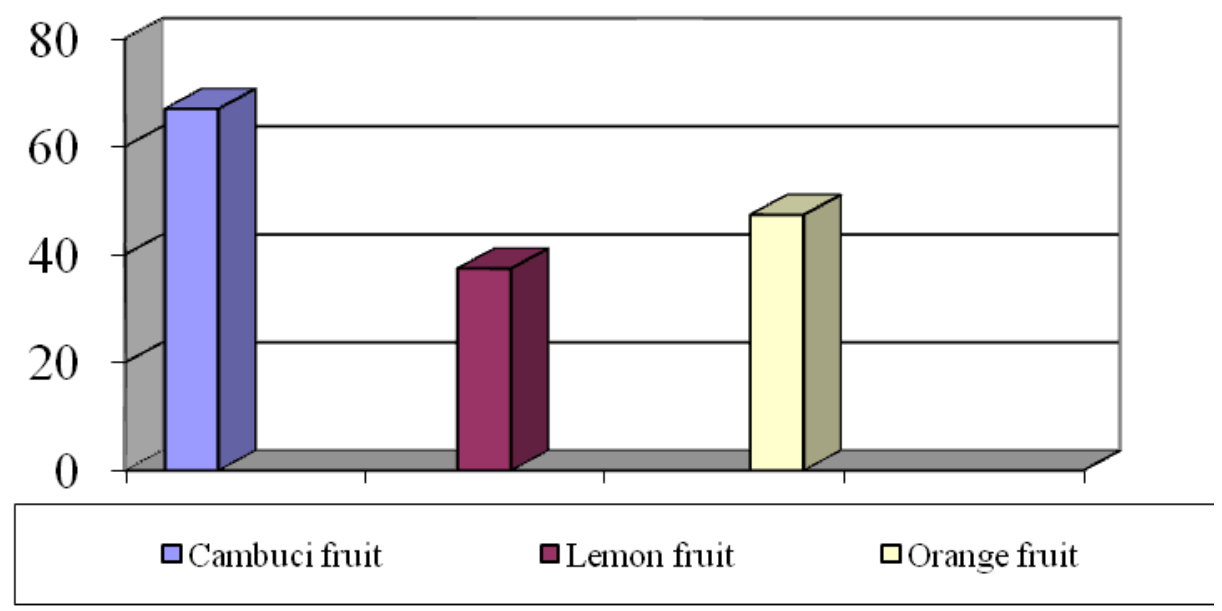

The results of ascorbic acid amounts presented significant differences between the agroindustrial process at a 5\% of statistical significance (Table 3 and Graph 2). The ascorbic acid initial average in frozen pulp is $92.84 \%$ out of the concentration on fresh fruit. The frozen-pasteurized pulp presented 76.25 $\%$ out of the concentration on fresh fruit. The ascorbic acids' initial average in frozen pulp represents $121.77 \%$ of the detected concentration in frozenpasteurized pulp.

\section{Graphic 2. Average Levels of Vitamin C Content in Agroindustrial Process}

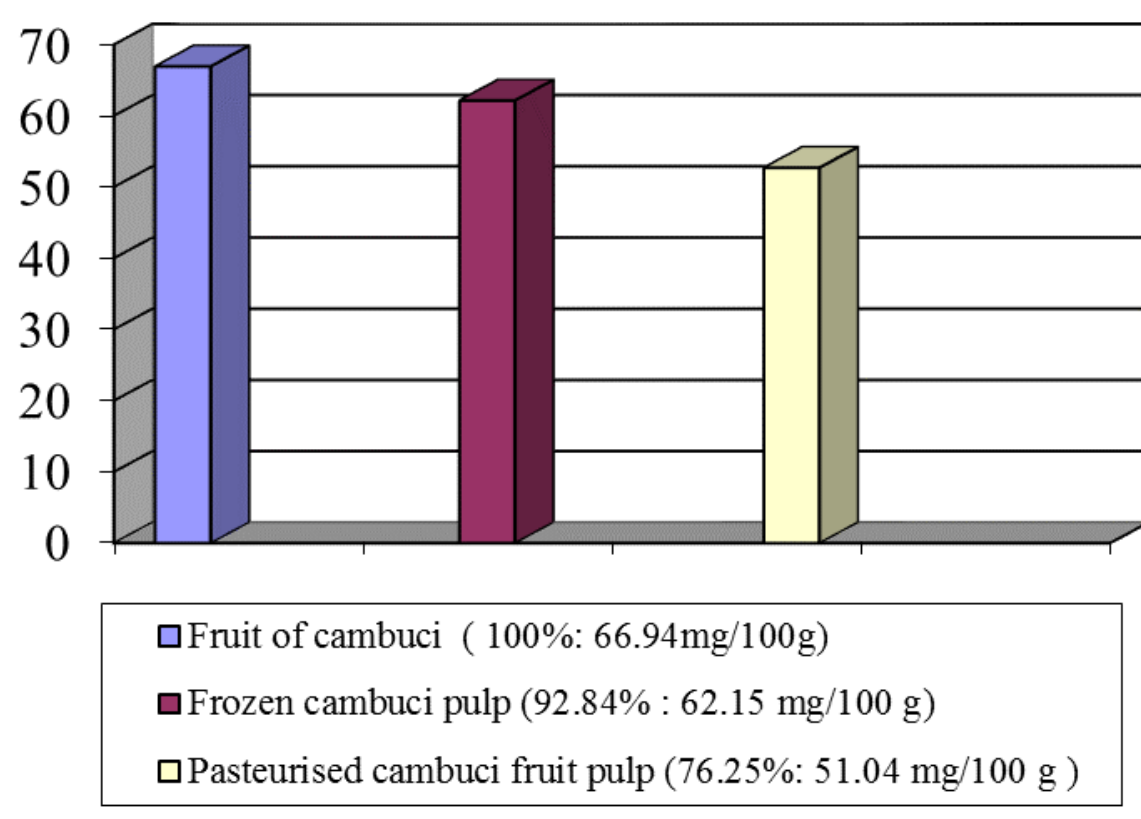

Along the storage period for both treatments, the analyzed cambuci pulps presented a significant reduction of the initial amount of vitamin $C$ (Table 3 and Graph 3), according to works about other species (Kabasakalis et al., 2000). After 90 days, the highest average percentage of accumulated loss was 
detected in frozen-pasteurized pulp (53.82\%), with an average of $23.57 \mathrm{mg}$ vitamin $\mathrm{C} / 100 \mathrm{~g}$. The frozen pulp presented the lower average percentage of loss $(48.66 \%)$, with an ascorbic acid average content of $31.91 \mathrm{mg} / 100 \mathrm{~g}$ at 90 days (Table 3 and Graph 3).

Table 3. Average Loss of Vitamin C in Storage Pulp Cambuci Samples for 90 Days: Frozen-pasteurized and Frozen Cambuci

\begin{tabular}{|c|c|c|c|c|}
\hline Day & $\begin{array}{c}\text { Frozen pulp } \\
\text { (mg of ascorbic acid / } \\
\text { 100g of pulp) }\end{array}$ & $\begin{array}{c}\text { Average } \\
\text { loss (\%) }\end{array}$ & $\begin{array}{c}\text { Frozen- pasteurized pulp } \\
\text { (mg of ascorbic acid / 100g } \\
\text { of pulp) }\end{array}$ & $\begin{array}{c}\text { Average } \\
\text { loss (\%) }\end{array}$ \\
\hline 01 & $62.15 \mathrm{~A} \mathrm{a}$ & 0 & $51.04 \mathrm{~B} \mathrm{a}$ & 0 \\
\hline 15 & $38.11 \mathrm{~A} \mathrm{~b}$ & 38.68 & $32.63 \mathrm{~B} \mathrm{~b}$ & 36,07 \\
\hline 30 & $36.48 \mathrm{~A} \mathrm{bc}$ & 41.30 & $30.45 \mathrm{~B} \mathrm{bc}$ & 40.34 \\
\hline 45 & $37.89 \mathrm{~A} \mathrm{bc}$ & 39,03 & $28.74 \mathrm{~B} \mathrm{bcd}$ & 43.69 \\
\hline 60 & $36.12 \mathrm{~A} \mathrm{bc}$ & 41.88 & $26.09 \mathrm{~B} \mathrm{~cd}$ & 48.89 \\
\hline 75 & $35.06 \mathrm{~A} \mathrm{bc}$ & 43.59 & $28.41 \mathrm{~B} \mathrm{bcd}$ & 44.33 \\
\hline 90 & $31.91 \mathrm{~A} \mathrm{c}$ & 48.66 & $23.57 \mathrm{~B} \mathrm{~d}$ & 53.82 \\
\hline
\end{tabular}

Graph 3. Correlation of Ascorbic Acid Concentration (ppm) (x) vs (y) Day of Storage

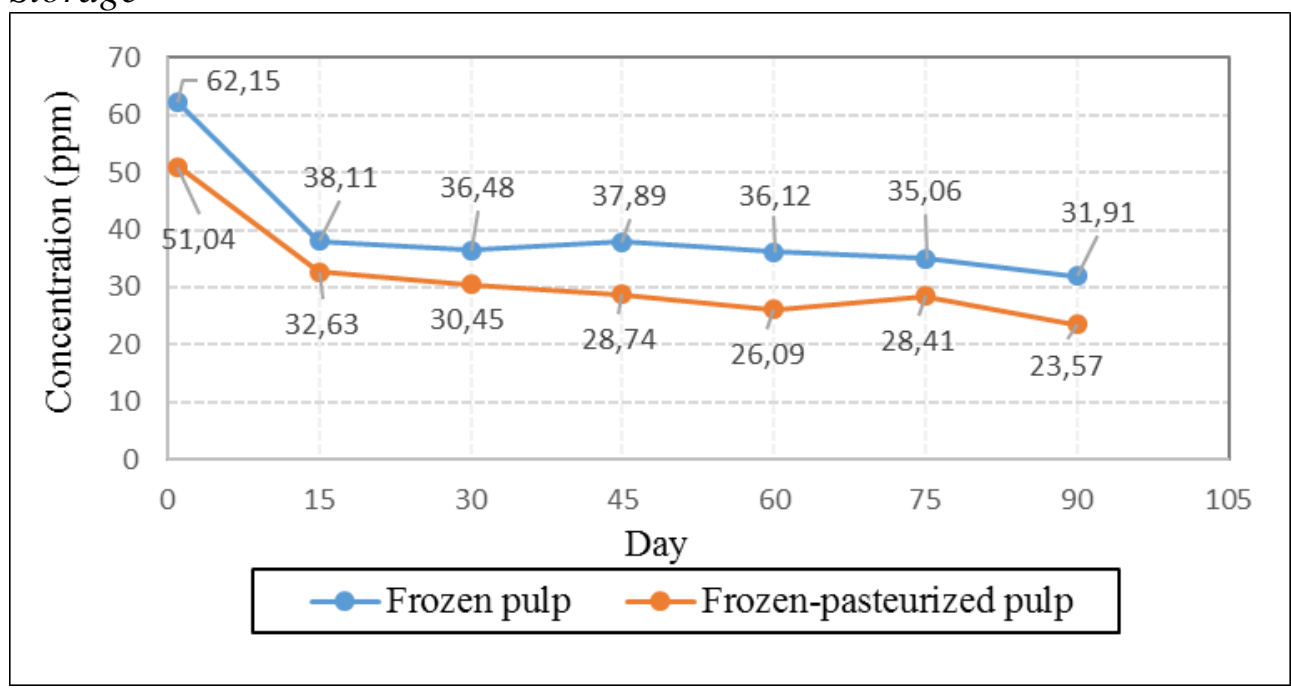

Lo Scalzo et al. (2004) founded the loss values to orange juice pasteurized $(42,69 \mathrm{mg}$ of ascorbic acid $/ 100 \mathrm{~mL})$ when compared to Frozen- pasteurized cambuci pulp (51.04 69mg of ascorbic acid /100mL of pulp).

According to Kabasakalis et al. (2000), along the storage period, the pasteurized orange juice after 31 days presented a significant reduction (13.08 $\mathrm{mg}$ of ascorbic acid / 100g of pulp) of initial amount of vitamin C.

After 30 days, an average of $30.45 \mathrm{mg}$ vitamin C / $100 \mathrm{~g}$ of pulp was detected in the cambuci pulp, that is a highest value than orange juice.

Because of its instability, the ascorbic acid could be an index to evaluate the effect from agroindustrial process on retention of nutrient (Polydera et al., 
2003). The results of this study demonstrated that ascorbic acid reduction was higher in frozen-pasteurized cambuci pulp than in frozen cambuci pulp. The processing method chosen, longer processing time, higher processing temperatures and cutting or maceration of the food have been known to cause significant losses of vitamins. High temperature accelerates reactions, which would occur more slowly at room temperature. However, freezing is enough to stabilize the ascorbic acid in storage fruit pulp.

\section{Conclusions}

To conclude, the cambuci fruit presented significant amounts of vitamin C compared with orange and lemon, proving that it can be an alternative source of vitamin C. Also the vitamin C losses were higher in pasteurization-frozen pulps (53.82 \% average loss) than in simply frozen pulps (48.66\% average loss). The pasteurization may increase the loss of vitamins at fruit's pulp. In the other hand, the ascorbic acid was relatively stable during storage post freezing process. Limited information is available on the ascorbic acid in cambuci at processing and storage. It is important implement other studies to complement the knowledge about the shelf-life of frozen and frozen-pasteurized pulp of cambuci fruit.

\section{References}

Abid, M., Jabbar, S., Wu, T., Hashim, M. M., Hu, B., Lei, S., \& Zeng, X. 2014. Sonication enhances polyphenolic compounds, sugars, carotenoids and mineral elements of apple juice. Ultrasonics Sonochemistry, 21(1): 93-97.

Adati, R. T. 2001. Estudo Biofarmacognóstico Campomanesia phaea (O. Berg.) Landrum. Myrtaceae [Study Biofarmacognóstico Campomanesia phaea (O. Berg.) Landrum. Myrtaceae]. Universidade de São Paulo, São Paulo, Brasil.

Adati, R. T., \& de Oliveira Ferro, V. 2006. Volatile Oil Constituents of Campomanesia phaea (O. Berg) Landrum. (Myrtaceae). Journal of Essential Oil Research, 18(6): 691-692.

Aguilar-Rosas, S. F., Ballinas-Casarrubias, M. L., Nevarez-Moorillon, G. V., MartinBelloso, O., \& Ortega-Rivas, E. 2007. Thermal and pulsed electric fields pasteurization of apple juice: Effects on physicochemical properties and flavour compounds. Journal of Food Engineering, 83(1): 41-46.

Asami, D. K., Hong, Y. J., Barrett, D. M., \& Mitchell, A. E. 2003. Processing-induced changes in total phenolics and procyanidins in clingstone peaches. Journal of the Science of Food and Agriculture, 83(1): 56-63.

Ayhan, Z., Yeom, H. W., Zhang, Q. H., \& Min, D. B. 2001. Flavor, Color, and Vitamin C Retention of Pulsed Electric Field Processed Orange Juice in Different Packaging Materials. Journal of Agricultural and Food Chemistry, 49(2): 669674.

Bezman, Y., Rouseff, R. L., \& Naim, M. 2001. 2-Methyl-3-furanthiol and Methional Are Possible Off-Flavors in Stored Orange Juice: Aroma-Similarity, NIF/SNIF 
GC-O, and GC Analyses. Journal of Agricultural and Food Chemistry, 49(11): 5425-5432.

Block, G., Patterson, B., \& Subar, A. 1992. Fruit, vegetables, and cancer prevention: A review of the epidemiological evidence. Nutrition and Cancer, 18(1): 1-29.

Bresolin, J., \& Hubinger, S. 2014. Metodologia para determinação de ácido ascórbico em sucos de citrus utilizando cromatografia líquida de alta eficiência [Methodology for determination of ascorbic acid in citrus juices using highperformance liquid chromatography]. Simpósio Nacional de Instrumentação Agropecuária, 497-500.

Cortes, C., Esteve, M. J., \& Frigola, A. 2008. Effect of refrigerated storage on ascorbic acid content of orange juice treated by pulsed electric fields and thermal pasteurization. European Food Research and Technology, 227(2): 629-635.

De Souza Schmidt Goncalves, A. E., Lajolo, F. M., \& Genovese, M. I. 2010. Chemical composition and antioxidant/antidiabetic potential of Brazilian native fruits and commercial frozen pulps. Journal of agricultural and food chemistry, 58(8): 4666-4674.

Donado-Pestana, C. M., Belchior, T., Festuccia, W. T., \& Genovese, M. I. 2015. Phenolic compounds from cambuci (Campomanesia phaea O. Berg) fruit attenuate glucose intolerance and adipose tissue inflammation induced by a highfat, high-sucrose diet. Food Research International, 69: 170-178.

Haminiuk, C. W. I., Plata-Oviedo, M. S. V., Guedes, A. R., Stafussa, A. P., Bona, E., \& Carpes, S. T. 2011. Chemical, antioxidant and antibacterial study of Brazilian fruits. International Journal of Food Science \& Technology, 46(7): 1529-1537.

Jayaprakasha, G., \& Patil, B. S. 2007. In vitro evaluation of the antioxidant activities in fruit extracts from citron and blood orange. Food Chemistry, 101(1): 410-418.

Kabasakalis, V., Siopidou, D., \& Moshatou, E. 2000. Ascorbic acid content of commercial fruit juices and its rate of loss upon storage. Food Chemistry, 70(3): 325-328.

Kalt, W., Forney, C. F., Martin, A., \& Prior, R. L. 1999. Antioxidant capacity, vitamin $\mathrm{C}$, phenolics, and anthocyanins after fresh storage of small fruits. Journal of Agricultural and Food Chemistry, 47(11): 4638-4644.

Kawasaki, M. L., \& Landrum, L. R. 1997. A rare and potentially economic fruit of Brazil, Campomanesia pheaea (Myrtaceae). Economic Botany, 51(4): 403-405.

Leão, M. M. 2012. Características do óleo essencial extraído das folhas de Campomanesia phaea (O. Berg.) Landrum (cambuci) obtido em duas microrregiões da Mata Atlântica. Escola Superior de Agricultura Luiz de Queiroz (ESALQ) Universidade de São Paulo (USP), Biblioteca digital da USP.

Lo Scalzo, R. et al. Effect of thermal treatments on antioxidant and antiradical activity of blood orange juice. Food Chem., v. 85, p. 41-47, 2004.

Lorenzi, H. 2014. Árvores brasileiras: manual de identificação e cultivo de plantas arbóreas do Brasil ( $6^{\mathrm{a}}$ Ed. ed.). Nova Odessa, SP: Instituto Plantarum.

Majo, D. D., Giammanco, M., Guardia, M. L., Tripoli, E., Giammanco, S., \& Finotti, E. 2005. Flavanones in Citrus fruit: Structure-antioxidant activity relationships. Food Research International, 38(10): 1161-1166.

Mathias, J., \& Andrade, G. A. 2011. Cambuci: nativa da mata atlântica, a árvore frutífera é também uma planta ornamental, mas está sob risco de extinção [Cambuci: native forest, the fruit tree is also an ornamental plant, but is at risk of extinction]. Globo Rural, Vol. 296: Editora Globo S.A.

Nicoli, M. C., Anese, M., \& Parpinel, M. 1999. Influence of processing on the antioxidant properties of fruit and vegetables. Trends in Food Science and Technology, 10(3): 94-100. 
Plaza, L., Sanchez-Moreno, C., Elez-Martinez, P., de Ancos, B., Martin-Belloso, O., \& Cano, M. P. 2006. Effect of refrigerated storage on vitamin $\mathrm{C}$ and antioxidant activity of orange juice processed by high-pressure or pulsed electric fields with regard to low pasteurization. European Food Research and Technology, 223(4): 487-493.

Polydera, A. C., Stoforos, N. G., \& Taoukis, P. S. 2003. Comparative shelf life study and vitamin $\mathrm{C}$ loss kinetics in pasteurised and high pressure processed reconstituted orange juice. Journal of Food Engineering, 60(1): 21-29.

Rapisarda, P., Bianco, M. L., Pannuzzo, P., \& Timpanaro, N. 2008. Effect of cold storage on vitamin $\mathrm{C}$, phenolics and antioxidant activity of five orange genotypes [Citrus sinensis (L.) Osbeck]. Postharvest Biology and Technology, 49(3): 348354.

Rawson, A., Patras, A., Tiwari, B. K., Noci, F., Koutchma, T., \& Brunton, N. 2011. Effect of thermal and non thermal processing technologies on the bioactive content of exotic fruits and their products: Review of recent advances. Food Research International, 44(7): 1875-1887.

Zafra-Stone, S., Yasmin, T., Bagchi, M., Chatterjee, A., Vinson, J. A., \& Bagchi, D. 2007. Berry anthocyanins as novel antioxidants in human health and disease prevention. Molecular Nutrition and Food Research, 51(6): 675-683.

Zulueta, A., Esteve, M. J., \& Frígola, A. 2010. Ascorbic acid in orange juice-milk beverage treated by high intensity pulsed electric fields and its stability during storage. Innovative Food Science \& Emerging Technologies, 11(1): 84-90. 
